\title{
Trends in Growth Convergence and Divergence and Changes in Technological Access and Capabilities*
}

\author{
Hugo Hollanders ${ }^{\mathrm{a}}$, Luc Soete ${ }^{\mathrm{b}, * *}$, Bas ter Weel ${ }^{\mathrm{a}}$ \\ ${ }^{a}$ Maastricht Economic Research Institute on Innovation and Technology (MERIT), \\ Maastricht University, Maastricht, the Netherlands \\ ${ }^{b}$ Department of Economics and Maastricht Economic Research Institute on Innovation and Technology (MERIT), \\ Maastricht University, the Netherlands
}

\begin{abstract}
This paper goes into detail in the pattern of growth over the last thirty to forty years at the world level. A model is developed in which different aspects of technological change and their influence on growth will be outlined. This model is used in estimations for cross-country OECD-samples of 1973-1996 growth paths, as well as in panel databases for yearly growth rates over the 1973-1996 period. In addition, an analytical technique is developed which identifies different empirical sources for specific convergence or divergence trends within the OECD area. Moreover, we show that traditional factors are only partially able to explain the recent divergence relative to the US. Hence, we introduce 'new' factors explaining this trend.
\end{abstract}

Keywords: Growth; Convergence; Codified knowledge; Tacit knowledge; Spillovers

JEL Classification: O4; O3.

\footnotetext{
* This paper builds in large part on ongoing research part of the World Knowledge Report, forthcoming. This paper was prepared for and presented at the Lisbon Workshop on "Cliometrics, Econometrics and Appreciative History in the Study of Long Waves in Economic Development”, Lisbon, 11-13 March 1999. Seminar participants are gratefully acknowledged for their comments.

*** Corresponding author. MERIT, P.O. Box 616, 6200 MD, Maastricht, the Netherlands. Tel: 0031-43-3883891; Fax: 003143-3216518; E-mail: luc.soete@algec.unimaas.nl.
} 


\section{Introduction}

It represents something of a voyage in the unknown to return after more than ten years to the subject of long waves. The last contribution of one of us (Soete, 1986) was, and aptly so, part of the volume of essays in honour of Christopher Freeman (MacLeod, 1986), and reviewed some of the long waves and technology literature written in the 1970s and 1980s. In it, it was concluded, that further long wave research (of Freeman) would hopefully shed further light on some of the possible policy implications, and in particular some guidelines as to the required institutional changes which might help in the transition from one to the other technological regime, and that the gathering of more systematic empirical evidence both of a historical, more eclectic as well as of a more rigorous statistical nature would become part of this research agenda. From this perspective, it is particularly refreshing to see how the strategic alliance between Christopher Freeman and Franciso Louça has succeeded in bringing together, for this conference, contributions which focus in large part on these two issues: Richard Nelson opening up the way for further integration of institutional economics with the sort of socioinstitutional long wave framework espoused by Freeman; David Landes, Roger Lloyd-Jones and Svante Lingarde by describing in historical detail particular revolutionary features of past developments; Jan Reijnders and Gerald Silverberg by providing further statistical evidence and rigour to the evidence on long term growth cycles.

Our contribution is more in the line with the one of Andrew Tylecote's, focussing on the most recent post-war period and raising the question whether a new growth phase might have been set in motion and whether the recent 'new' growth evidence witnessed in the US, might be heralding a new, different growth cycle. In making our case, we will not try to stick to a very rigorous long wave hypothesis, rather we will focus on the structural changes as they appear to emerge from international growth data. For memory the long-term pattern of growth has been strikingly uneven between countries, questioning the simple convergence hypothesis popular in many growth models developed in the 1950s and 1960s. Over the last twenty to thirty years, thereby ignoring the period of reconstruction after the Second World War, the pattern of growth at the world level seems even to have been characterized by increasingly diverging growth trends, both within the group of developed OECD-countries as well as for other geographical groups of developing countries. These diverging growth trends are even more surprising given the convergence in aggregate macroeconomic indicators such as e.g. inflation; the opening up and 
formal adherence of many countries in the world to open, free trade principles with a rapid increase in world trade and international investment flows and the increasing trend towards international access to information and codified pieces of knowledge. The main hypothesis put forward in many of the catching up theories of the 1970s and 1980s was that relatively backward countries grow faster than advanced countries, because they would be able to imitate technological knowledge, and hence converge to the frontier value of per capita income more rapidly. ${ }^{1}$ Over the 1980 s and the early $1990 \mathrm{~s}$ many authors have focussed on such 'catching-up' growth models with emphasis on the particular role of technology accumulation. ${ }^{2}$ More recently, with the surge in 'new' growth contributions, additional factors have been added to the analysis, such as human capital. ${ }^{3}$

In this paper we go, in Section 2, in somewhat more detail in the pattern of growth over the last thirty to forty years at the world level. We develop in Section 3 a model in which different aspects of technological change and their influence on the slowdown on growth convergence is outlined. The model is used in estimations for cross-country OECD-samples of 1975-1996 growth paths, as well as in panel databases for yearly growth rates over the 1975-1996 period. Hence we identify different empirical sources for specific convergence or divergence trends within the OECD area. We then argue in Section 4 at a more eclectic descriptive level, how the most recent evidence on growth divergence amongst OECD countries and in particular between the US, Europe and Japan might be heralding a 'new' growth path based on an emerging knowledge-based economy. Section 5 summarizes the main arguments.

\footnotetext{
${ }^{1}$ Early examples of such approaches can be found in Gerschenkron (1962) and Cornwall (1977).

${ }^{2}$ E.g. Abramovitz (1979), (1986) and (1992), Pavitt and Soete (1982) and Fagerberg (1988).

${ }^{3}$ E.g. Mankiw, Romer and Weil (1992) and Baumol, Blackwell and Wolff (1989).
} 


\section{Convergence and Divergence: Evidence for the Twentieth Century}

The history of the development path of the by now industrialized (OECD) countries is often described as one being dominated by convergence. Hence, many growth contributions have shown that over the postwar period the least developed OECD economies have increased per capita GDP at the highest rate. ${ }^{4}$ At the same time, however, and suggested by e.g. Moses Abramovitz (1992), the postwar period is by and large an exceptional period. Analysis of other, longer, historical periods questions the simple convergence hypothesis. Hence, and based on some of the early work of Bart Verspagen (1991), empirical evidence on the growth trends in a sample of OECD-countries over the entire twentieth century is examined. ${ }^{5}$ The aim of this exercise is to find out to what extent the convergence trend is specific to the postwar period.

In order to highlight some of the peculiarities of the catching-up phenomenon, Figure 1 presents for the whole period of the twentieth century trends on growth convergence and divergence. The line, defined as $V_{t}$, gives the average percentage distance from the frontier value of per capita GDP for eighteen OECD-countries over the twentieth century. ${ }^{6}$ Denoting per capita GDP by $\ddot{Y}$, using subscripts $i$ and $t$ for countries and time, respectively, the indicator $V_{t}$ is defined as:

$$
V_{t}=\frac{1}{n} \sum_{i=1}^{n} \ln ^{2} \ddot{Y}_{i t}^{*}
$$

where $\ddot{Y}_{i t}^{*}$ is defined as per capita GDP relative to the US:

$$
\ddot{Y}_{i t}^{*}=\frac{\ddot{Y}_{i t}}{\ddot{Y}_{u s, t}}
$$

\footnotetext{
${ }^{4}$ Among which are Abramovitz (1979) and (1986), Baumol (1986) and Dowrick and Nguyen (1989).

${ }^{5}$ See also Soete and Verspagen (1994).

${ }^{6}$ These eighteen countries are Austria, Australia, Belgium, Canada, Denmark, Finland, France, Germany, Italy, Japan, Netherlands, New Zealand, Norway, Spain, Sweden, Switzerland, United Kingdom and the United States.
} 
A downward (upward) trend in the figure indicates convergence (divergence) to the frontier value $Y_{u s, t}$ the US.

It can be observed that before the Second World War there was little evidence of any strong convergence or divergence tendencies (except perhaps for the Great Depression period). The Second World War created of course huge per capita income disparities, with the leading country (US) not being affected by the mass destruction of its production means, as were many European countries and Japan.

Figure 1

Convergence and Divergence among Eighteen OECD-Countries in the Twentieth Century

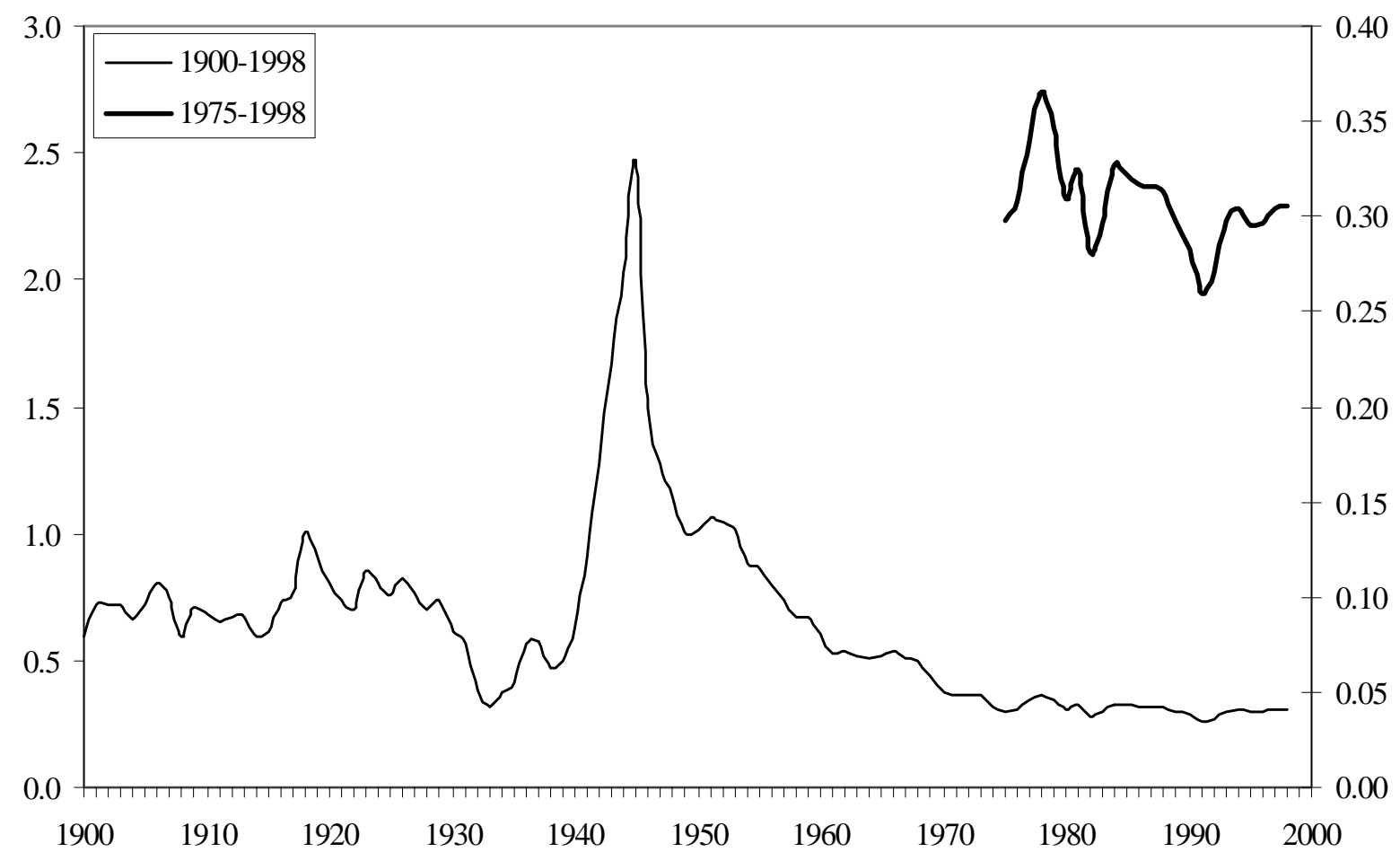

Four main periods in the twentieth century can be distinguished when investigating Figure 1, i.e. 19001938, 1950-1973, 1973-1991 and 1991-1998 (or most recent available). The first three periods as such show a converging trend, which can by and large be explained by the fact that after the Second World War income inequality between OECD-countries falls back to pre-war levels as a result of building up 
the economies again. Furthermore, the 1973-1991 period is characterized by a major further opening up of OECD economies and hence a boost in international trade leading to a further converging pattern. Indeed as Ben-David and Loewy (1998) emphasize, the role of heightened trade can have positive effects on the long-run growth rate of a country. Moreover, these authors show, in a steady-state context, that unilateral (and multilateral) trade liberalization generates a positive impact on the growth of all trading countries. Finally the period from 1991 on shows a diverging trend pointing towards a widening gap with the US is increasing. The causes, consequences and reasons for this divergence are outlined, discussed and explained below.

Figure 2 shows the relative growth performance, i.e. growth of per capita GDP, of our sample of OECD countries relative to the US. All four periods shown, i.e. 1913-1938, 1950-1973, 1973-1991 and 19911998, show a convergence pattern between the group of followers. This is explicitly tested in Table 1, where we have estimated the growth of per capita income relative to the US for each of the four periods as follows:

$$
\hat{Y}_{i t}^{*}=\omega+\mu Y_{i 0}^{*}
$$

where $Y_{i 0}{ }^{*}$ is defined as $Y_{i 0} / Y_{u s, 0}$. Equation (3) measures so-called $\beta$-convergence. The growth rate of relative per capita GDP is assumed to be negatively related to the level of relative per capita GDP in the first year of the time period considered. The expected sign for $\beta$ is thus negative. Table 1 shows the estimates for the four time periods.

\section{Table 1}

$\beta$-convergence for per capita GDP

\begin{tabular}{lccc}
\hline & $\omega$ & $\boldsymbol{\mu}$ & $\mathbf{R}^{\mathbf{2}} \mathbf{a d j}$. \\
\hline $1913-1938$ & 1.623 & -1.732 & 0.174 \\
& $(0.582)$ & $(0.829)$ & \\
$1950-1973$ & 5.020 & -6.293 & 0.786 \\
& $(0.495)$ & $(0.814)$ & \\
$1973-1991$ & 2.724 & -3.084 & 0.288 \\
& $(3.223)$ & $(1.129)$ & \\
$1991-1998$ & 3.841 & -5.542 & 0.353 \\
& $(2.688)$ & $(1.778)$ & \\
\hline
\end{tabular}

Note: standard errors in brackets. 
Figure 2

Convergence and divergence relative to the US
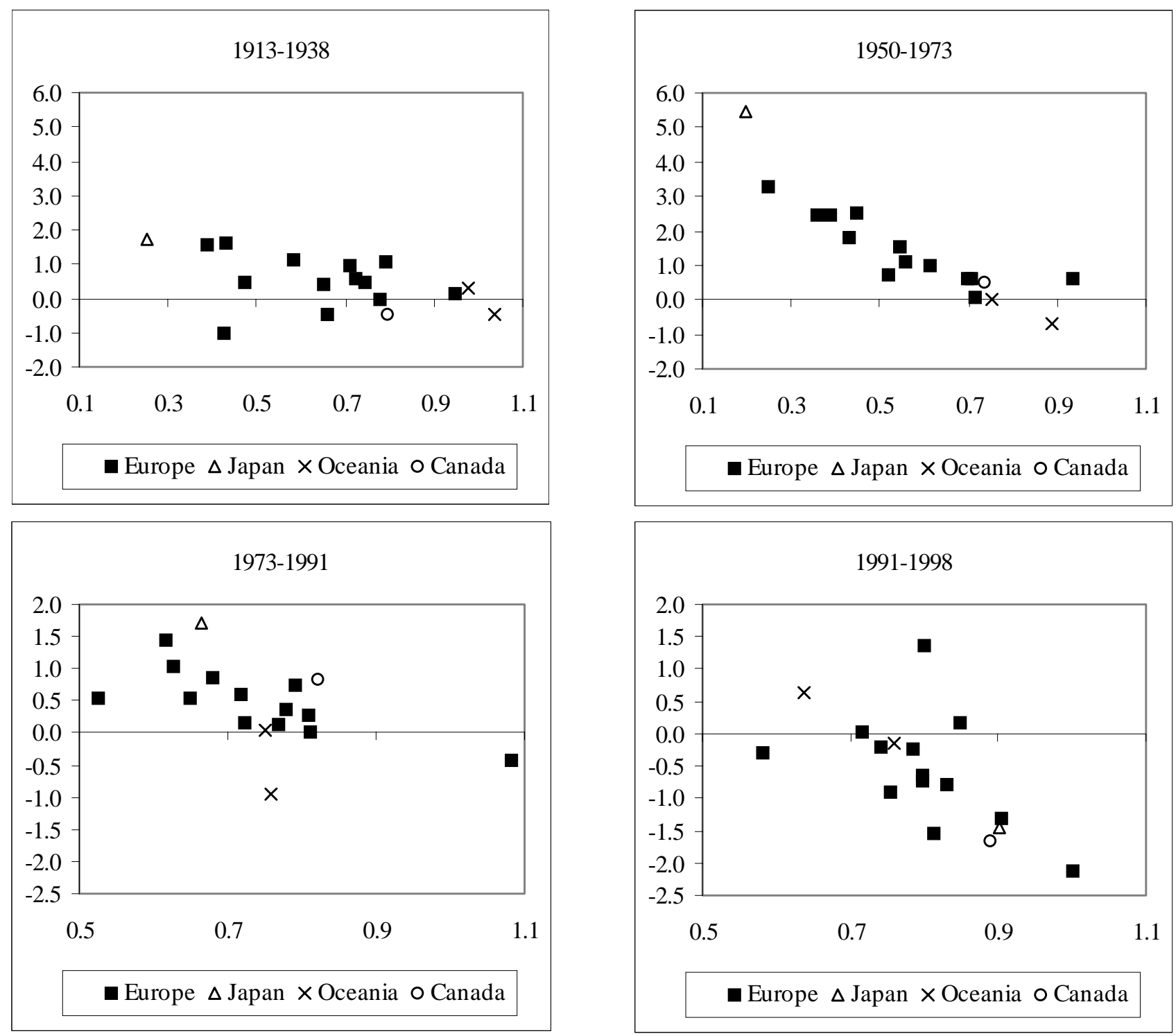

In all time periods $\beta$-convergence shows up significantly pointing to convergence between the countries following the US. However, and as also shown by Figure 2, there has been a major shift from a general trend of catching-up to the US to a trend of the US increasing its lead in the most recent period 19911998. This period shows also strong convergence between the EU-countries (with Norway being the exception), whereas the EU as a group just as Japan is falling behind the US. 
When focussing in more detail on the last thirty years, not just for the OECD-countries but for all countries at the world level, a much more complex pattern emerges. In order to avoid some of the tautological problems involved in comparative growth analyses, we define, apart from the OECDcountries (using the 1960 definition), six other geographical regions: Middle and South America, Middle East and North Africa, South-East Asia, Eastern Europe, Sub-Saharan Africa and Other Asian and Pacific countries. ${ }^{7}$ Furthermore, we divide the period 1960-1998 into three sub-periods: the period from 1960 up to the first oil crisis in 1973, the period 1973-1991 and the most recent period 1991-1998. For each period and for each of the group of countries, we computed the so-called 'motion of the gap' following Verspagen (1993). Define the relative per capita income gap (denoted by $G$ ) between country $i$ and the US as follows:

$$
G_{i t}=\ln \left(\frac{Y_{u s, t}}{Y_{i t}}\right)
$$

The logarithmic specification is used to obtain the convenient property that for equal values of per capita income levels, the income gap is zero. In order to measure the growth performance of a country, the average motion of $G$ over time can be measured by estimating the following equation for the three periods ( $\epsilon$ is an error term with the usual properties).

$$
G_{i t}=\varphi+\xi_{i} t+\epsilon_{i t}
$$

Table 2 summarizes the various trends in these three time periods for each of our seven groups.

\section{Table 2}

\footnotetext{
${ }^{7}$ Annex 1 provides a list of the countries included in the several groups.
} 
General Patterns of Convergence and Divergence

\begin{tabular}{lrrr}
\hline Regions & $1960-1973$ & $1973-1991$ & $1991-1998$ \\
\hline Sub-Saharan Africa & - & -- & -- \\
Middle East and North Africa & ++ & $+/-$ & $+/-$ \\
South East Asia & ++ & ++ & ++ \\
Other Asia and Pacific & $+/-$ & + & + \\
Middle and South America & $+/-$ & - & $+/-$ \\
OECD & ++ & ++ & $-/+$ \\
Eastern Europe & + & + & - \\
\hline
\end{tabular}

++ strong convergence; + convergence; +/- mixed results tending towards convergence; -/+ mixed results tending towards divergence; - divergence; -- strong divergence

Source: Hollanders, Soete and Ter Weel (1999)

To highlight the nature of the general pattern summarized in Table 2, one may refer to Robert Lucas' description of the growth puzzle (Lucas, 1993). The Philippines and South Korea had in 1960 about the same standard of living, as measured by their per capita GDPs of about US\$640. ${ }^{8}$ In addition, population, urbanization, primary and secondary school enrollment were similar. Given those nearly identical starting points, how can it be that over the next twenty five years Korea 'made a miracle', on average annual GDP per capita grew by $6 \%$, while the Philippines stagnated at about $2 \%$ ? Lucas finds the answer in a neoclassical framework with a strong focus on technology, while other growth economists such as Roland Bénabou (1996) suggest that the answer to the puzzle may lie outside the traditional factor endowment framework by noting that the Gini coefficient, a measure of the degree of concentration of income and wealth, was much higher in the Philippines than in South Korea indicating how initial inequality could have negative effects on growth performance in the Philippines.

1960-1973: A general period of convergence

\footnotetext{
${ }^{8}$ The US\$640 are measured using 1975 PPP ratios.
} 
The period 1960-1973 is, as illustrated in Table 2, characterized by rapid economic growth and development and a general continuation of a relatively stable rebuilding process after the Second World War, with the exception of the newly independent African countries. Hence, a global pattern of convergence of per capita income towards the United States' level is found. Figure 3 shows the evolution of the world economy during this period. From this diagram, and Table 2, it is clear that all OECD-countries, except for Luxembourg, New Zealand and the United Kingdom, were strongly converging, while the same argument goes for the South East Asian and Middle East and North African countries. The Eastern European countries also converge towards the United States but less rapidly than the South East Asian and Middle East and North African countries. Sub-Saharan African countries clearly diverge, except for some small countries. Finally, the other Asian and Pacific countries and the Middle and South American countries show a diverse pattern.

Figure 3

Motion of the Gap 1960-1973

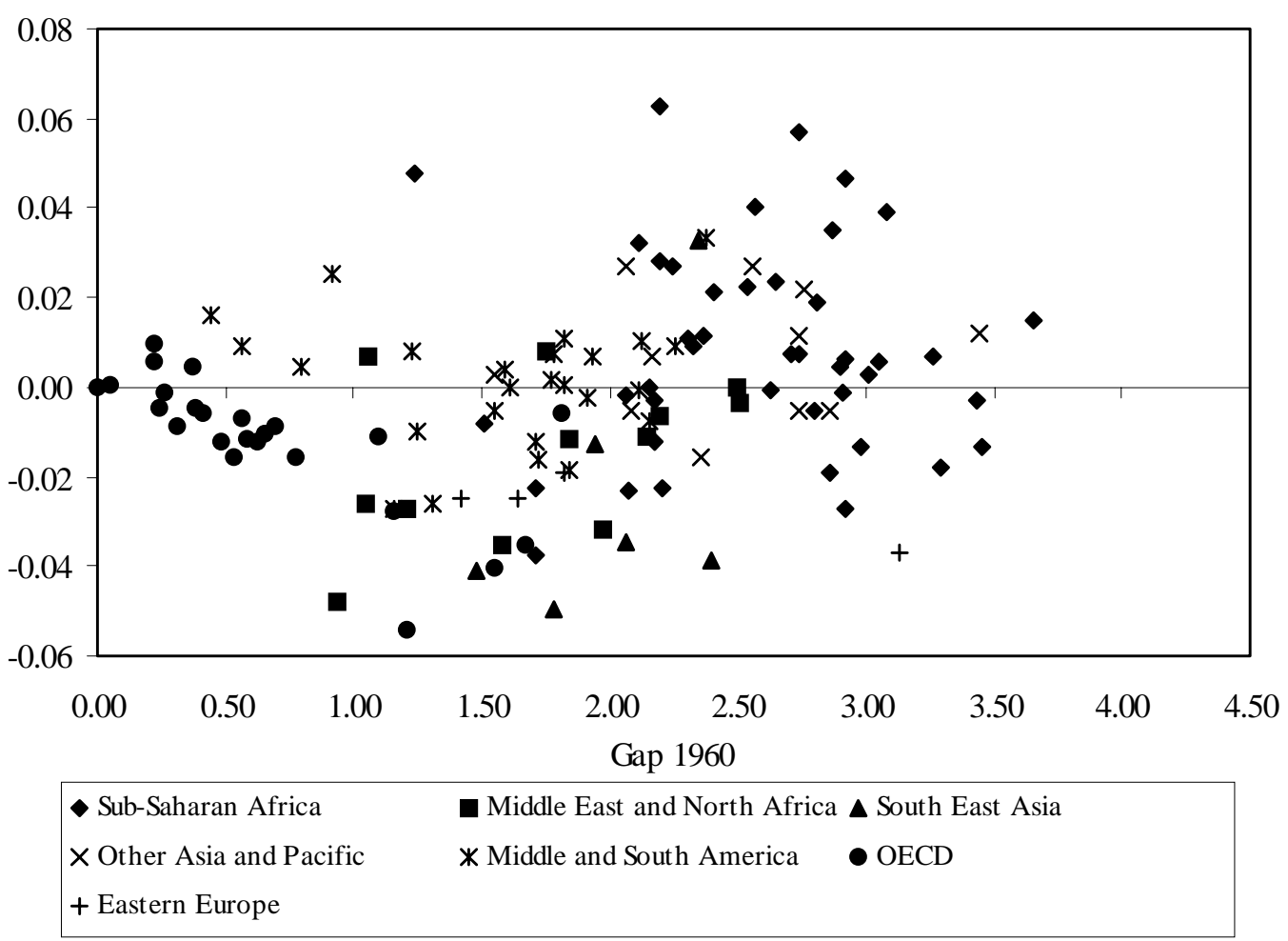

Source: Hollanders, Soete and Ter Weel (1999) 


\section{3-1991: A mixed period of growth convergence and divergence}

This period starts off with the first oil crisis and includes both the second oil crisis and several financial crises of which the 1987 Wall Street Black Monday crash is the most notable. It is a period of less growth but with still a dominant trend in convergence in the OECD, Eastern European and South East Asian countries as Figure 4 illustrates, even though the motion of the gap is less strong than in the previous period. Again African countries are diverging, while the Middle and South American countries also perform worse and diverge in general.

Figure 4

Motion of the Gap 1973-1991

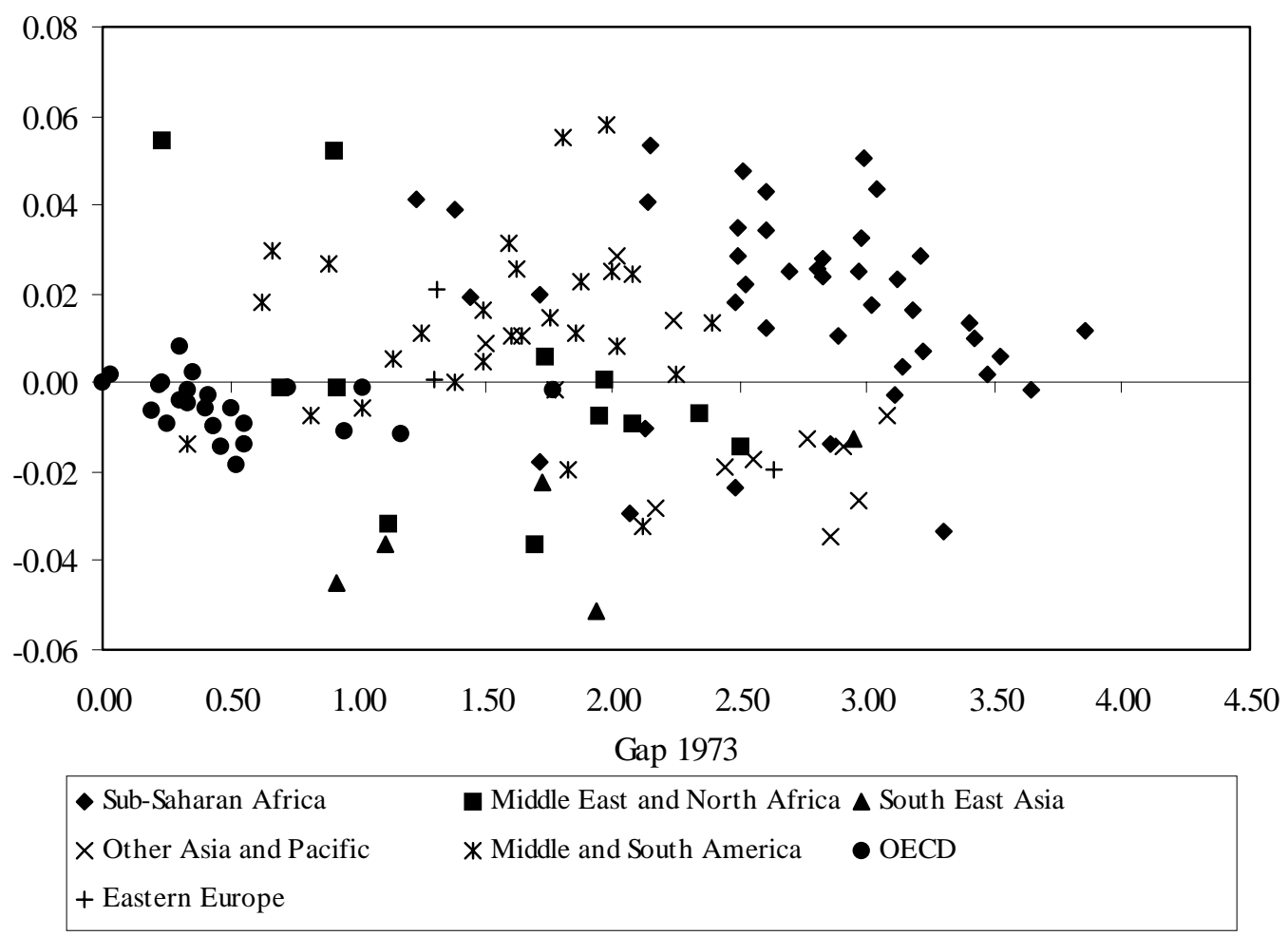

Source: Hollanders, Soete and Ter Weel (1999)

1991-1998: A period of new growth divergence?

Figure 5 shows the general picture for the period 1989-1998. The growth pattern is much more diverse than the pattern obtained in the previous two periods. The most notable change is the divergence among 
OECD-countries, illustrating the growth divergence relative to the United States. In addition, the Eastern European, as a result of the end of the 'socialist experiment', are now also diverging quite strongly. The evidence for the Middle East and North African and Middle and South American countries is mixed with some countries converging but most countries diverging. Interestingly, the South East Asian countries are all still strongly converging over this period, the Asian crisis not yet having fully affected growth rates (figures only up to 1997).

\section{Figure 5}

Motion of the Gap 1991- most recent

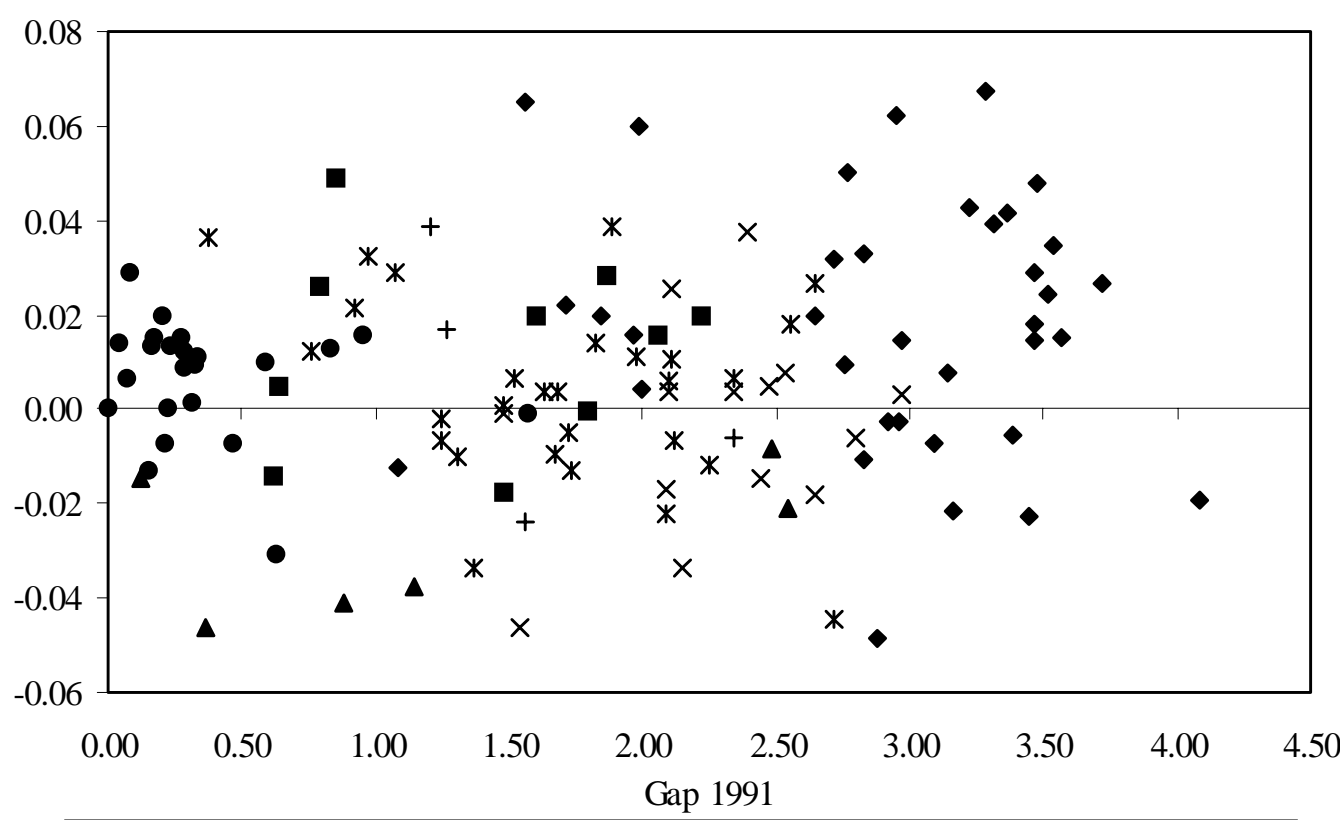

- Sub-Saharan Africa

- Middle East and North Africa $\Delta$ South East Asia

$\times$ Other Asia and Pacific

* Middle and South America

- OECD

+ Eastern Europe

Source: Hollanders, Soete and Ter Weel (1999)

\section{How Much of the Convergence Slowdown Can be Explained by Technology?}

As shown previously, convergence has slowed down since the 1970s and has even turned into divergence in the 1990s, especially within our sample of eighteen OECD countries. Figure 6 presents 
the value of $V$ over the period 1975-1998 for this OECD-sample. This figure shows a pattern of divergence starting from 1991 onwards. The figure presents the indicator $V$ for both per capita GDP and labour productivity which is constructed using equation (2).

\section{Figure 6}

Convergence and Divergence among Eighteen OECD-Countries: 1975-1998

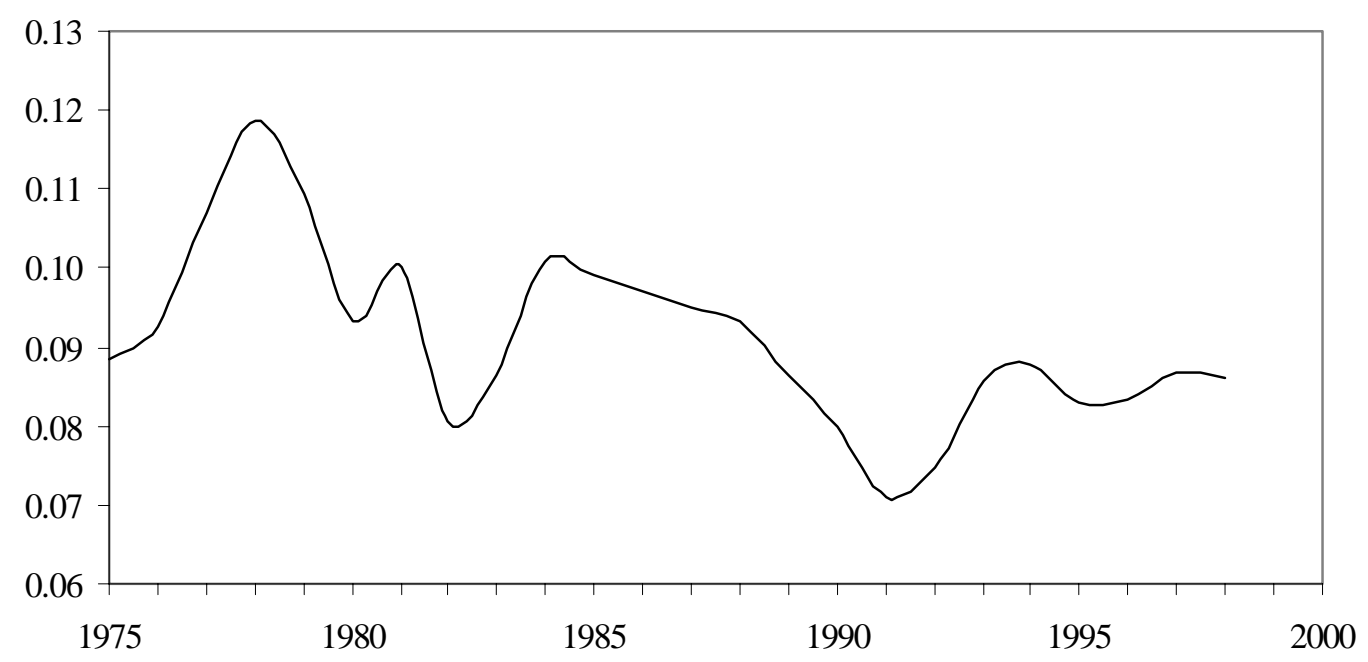

The question we will try to answer in this section is: What factors can explain this turn in convergence/divergence behaviour? The approach followed, similar to the analysis developed in Verspagen (1994), is to decompose the time derivative of $V$ into the separate factors to explain changes in convergence/divergence.

Consider the following Cobb-Douglas production function:

$$
Q_{i t}=e^{A_{i}+\gamma t} K_{i t}^{\alpha} L_{i t}^{\beta} R_{i t}^{\rho} P_{i t}^{\pi} F_{i t}^{\lambda}
$$

where $Q$ is output, $K$ is physical capital stock, $L$ is labour input, $R$ is R\&D capital stock, $P$ is patent stock, and $F$ represents catch-up factor due to disembodied knowledge spillovers. $A$ is a country-specific scale factor and $\gamma$ is the exogenous rate of technological progress. 
The level of a variable $X_{i t}$ relative to the US, the reference country, is denoted by an * as follows:

$$
X_{i t}^{*}=\frac{X_{i t}}{X_{u s, t}}
$$

The annual growth rate of a variable $X_{i t}$ is defined as:

$$
x_{i t}=\ln \left(X_{i t}\right)-\ln \left(X_{i, t-1}\right)
$$

Finally, labour productivity is defined as:

$$
Y_{i t}=\frac{Q_{i t}}{L_{i t}}
$$

Following Dowrick and Nguyen (1989), the change in the potential for disembodied knowledge spillovers is defined to be inversely related to country $i$ 's relative, i.e. relative to the US, labour productivity:

$$
\frac{F_{i t}}{F_{i, t-1}}=\left(\frac{1}{Y_{i, t-1}^{*}}\right)^{-1}
$$

Expressing all variables in equation (6) relative to the US, then rewriting the equation in natural logarithms, taking first differences and finally substituting $F_{i t}$ from equation (10), leads to the following expression for the relative growth rate of output:

$$
q_{i t}^{*}=\alpha k_{i t}^{*}+\beta l_{i t}^{*}+\rho r_{i t}^{*}+\pi p_{i t}^{*}-\lambda \ln \left(Y_{i, t-1}^{*}\right)
$$

Constructing a panel database for our sample of eighteen countries ${ }^{9}$, the parameters can be estimated using a 'within' regression. In order to account for business cycle effects, we have included dummy variables for the recession periods in 1974-75, 1980-82 and 1991-93. The results are presented in Table 3.

\footnotetext{
${ }^{9}$ The regression is only performed for seventeen countries, as the US, the reference country, is not included.
} 
Table 3

Regression Results Panel Database

\begin{tabular}{cccccccccc}
\hline & $\mathbf{k}$ & $\mathbf{l}$ & $\mathbf{r}$ & $\mathbf{p}$ & $\ln \mathbf{Y}$ & $\mathbf{d}_{\mathbf{1}}$ & $\mathbf{d}_{\mathbf{2}}$ & $\mathbf{d}_{\mathbf{3}}$ & $\mathbf{R}^{\mathbf{2}} \mathbf{a d j} \mathbf{~}$ \\
\hline$(1)$ & 0.368 & 0.392 & 0.115 & & -0.087 & -0.130 & -0.029 & -0.014 & 0.249 \\
& $(0.101)$ & $(0.060)$ & $(0.055)$ & & $(0.018)$ & $(0.006)$ & $(0.006)$ & $(0.006)$ & \\
$(2)$ & 0.377 & 0.399 & 0.119 & 0.011 & -0.101 & -0.014 & -0.029 & -0.013 & 0.255 \\
& $(0.106)$ & $(0.061)$ & $(0.056)$ & $(0.027)$ & $(0.020)$ & $(0.006)$ & $(0.006)$ & $(0.006)$ & \\
\hline
\end{tabular}

Note: standard errors in brackets.

The second regression in Table 3 shows that all estimated coefficients are statistically significant except for the patent stock. The catch-up variable, i.e. the one representing disembodied knowledge spillovers, is highly significant, stressing the importance of these spillovers. The time dummies show that on average economic growth was about $1.5 \%$ lower during the recessions of the 1970s and 1990s, and about $3 \%$ during the recession of the 1980s.

In order to decompose the change of the variance-indicator $V_{t}$ over time, we differentiate equation (1) with respect to $Y_{i t}$ :

$$
\frac{\partial V_{t}}{\partial Y_{i t}^{*}}=2 \frac{\ln Y_{i t}^{*}}{Y_{i t}^{*}}
$$

Equation (11) can easily be rewritten to obtain the growth rate of labour productivity:

$$
y_{i t}^{*}=\alpha k_{i t}^{*}+(\beta-1) l_{i t}^{*}+\rho r_{i t}^{*}+\pi p_{i t}^{*}-\lambda \ln Y_{i, t-1}^{*}
$$

Combining equations (12) and (13), we obtain the following equation:

$$
\frac{\partial V_{t}}{\partial Y_{i t}^{*}}=2 Y_{i, t-1}^{*}\left(\alpha k_{i t}^{*}+(\beta-1) l_{i t}^{*}+\rho r_{i t}^{*}+\pi p_{i t}^{*}-\lambda \ln \left(Y_{i, t-1}^{*}\right)\right) \ln \left(Y_{i t}^{*}\right)
$$

Summing this expression over the $n$ countries, we obtain the total predicted change in $V$. If we then 
group together the terms with $k_{i}{ }^{*}, l_{i}{ }^{*}, r_{i}{ }^{*}, p_{i}{ }^{*}$ and $\ln \left(Y_{i, t-1}{ }^{*}\right)$, we can determine the influence of each of these factors on the change in $V$.

Figure 7

Sources of Convergence and Divergence over the Period 1975-1996

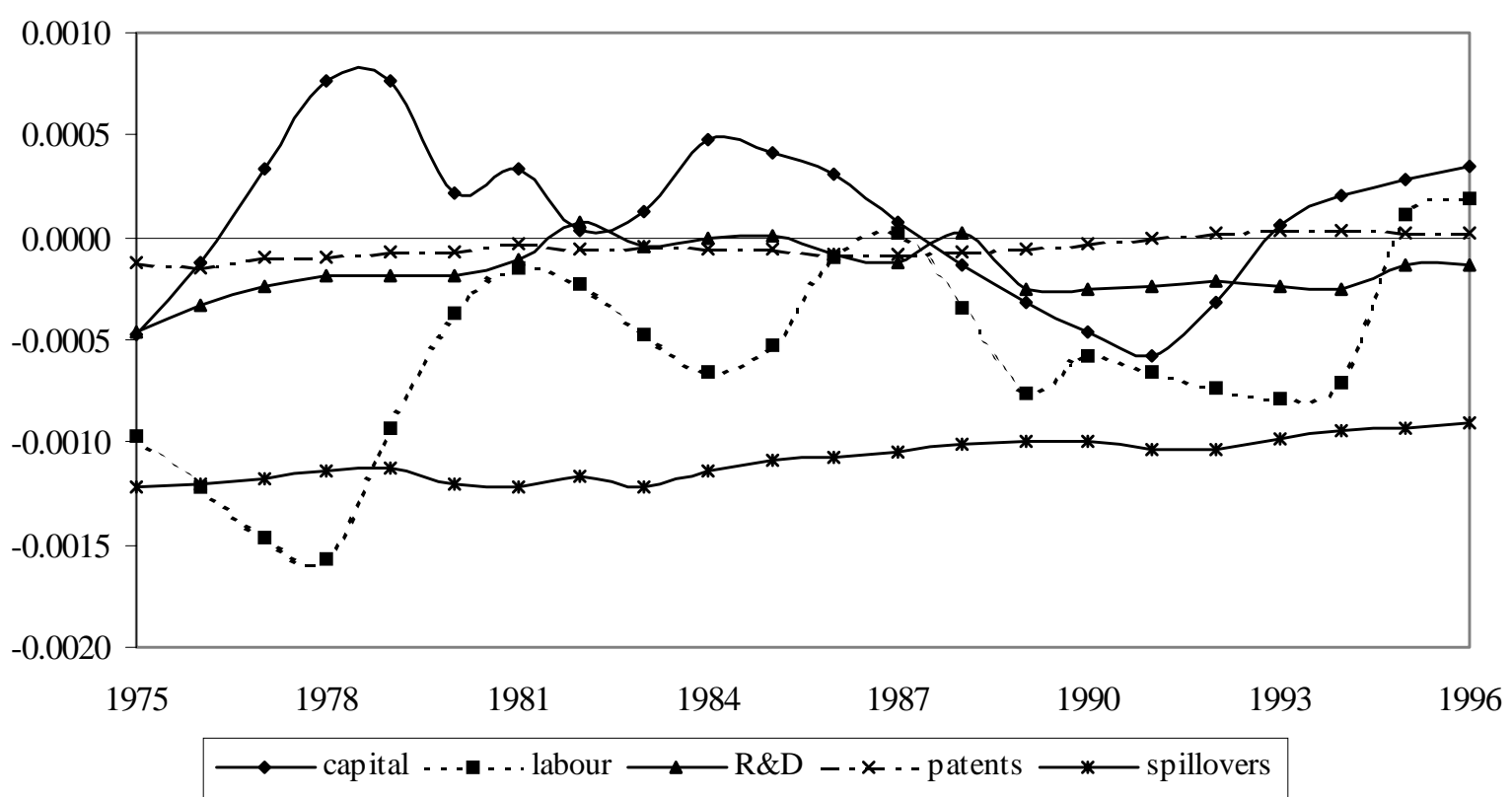

The variables in our panel-database, as well as the parameter estimates obtained, have been used to calculate the influence of the growth of labour inputs, capital stock, R\&D stock, and patent stock, and spillovers on the change in the indicator $V$. The outcomes of this exercise are compared to both the actual change in $V$ as well as the predicted change in $V .{ }^{10}$ The results of the calculations are in shown Table 4 and Figure 7. The figure has the exact values of each of the factors for the years 1975-1996. Because short run growth rates of the underlying variables were used, the lines in the figures show a high degree of variability from period to period. Although this feature is clearly artificial, the general

\footnotetext{
${ }^{10}$ For this, a simple AR(1) estimate for $V$ has been constructed:$$
V_{t}=0.056(0.014)+0.507(0.120) V_{t-1}
$$

with $\mathrm{R}^{2}$ adjusted $=0.444$. 
trend of the lines, as well as their relative (vertical) positions display some useful information. The table summarizes this information, by giving averages over two different periods, i.e. 1975-1991 and 19911996.

First, the results show that, in both periods used in the table, knowledge spillovers are the most important sources for convergence (i.e., the negative values of $V$ ). Labour inputs, patents, and capital investment play a much less important role in this respect. This supports the contemporary argument of knowledge creation as the driving force for growth and convergence. Moreover, it supports the distinction between different forms of technological change and knowledge creation, with imitation being a much more important source for convergence than innovation.

\section{Table 4}

Decomposition of Convergence and Divergence Trends, 1975-1996

\begin{tabular}{lccr}
\hline & $\mathbf{1 9 7 5 - 1 9 9 1}$ & $\mathbf{1 9 9 1 - 1 9 9 6}$ & change \\
\hline Capital & 0.00233 & -0.00001 & 0.00234 \\
Labour & -0.01032 & -0.00258 & -0.00774 \\
R\&D & -0.00233 & -0.00121 & -0.00112 \\
Patents & -0.00117 & 0.00013 & -0.00130 \\
Spillovers & -0.01801 & -0.00582 & -0.01219 \\
Total & -0.02951 & -0.00950 & -0.02000 \\
True & -0.03106 & -0.00643 & -0.02462 \\
Predicted & -0.02823 & -0.00296 & -0.02527 \\
\hline
\end{tabular}

From the above analysis it is clear that we are only partially able to explain the diverging pattern observed in Figure 1 and 2. This indicates that traditional factors such as capital, labour, R\&D and patents are not the key factors explaining recent divergence relative to the US. In the next section we elaborate on the 'new' factors causing this pattern of divergence relative to the US. 


\section{New Growth and the Emerging Knowledge-Based Economy}

The patterns described above continue to be analysed at an aggregate level, which does not provide much insight into the underlying factors explaining the observed shifts in growth convergence and divergence. Nevertheless, the aggregate trends described are surprising from more than one perspective.

Whereas the period up to 1973 can be characterised by a period of rapid growth, particularly in the industrialised countries, it was a period dominated by catching-up phenomena: catching up of European consumption patterns to US standards; significant growth in the centrally planned economies based on further exploitation of 'Tayloristic' methods of labour organisation in agriculture and the heavy industrial sectors, ${ }^{11}$ and the end of the decolonisation process in most Third World countries. It was in the logic itself of such growth process that the gap between the US and these countries was to narrow down. By contrast, the US economy did, if anything, show some major weaknesses, for example in relation to employment creation. ${ }^{12}$

In contrast, the 1973-91 period appears to be characterised by the disappearance of such catching-up features at least with respect to the European developed OECD world and Japan. This happened despite accelerated European economic integration with the subsequent enlargements of the European Community and the move from a customs union to an economic union. It also took place despite the gradual liberalisation of financial markets. In fact the period was characterised first by a dramatic explosion of exchange rate volatility, inflation, unemployment and public deficits. The failure of macroeconomic policies to contain inflation, reduce unemployment particularly in Europe, and control public spending are from this perspective both consequence and cause of the halt of growth convergence and what European economists referred to as 'les trentes glorieuses': the thirty wonder years of high growth, low inflation and low unemployment.

Finally, the most recent period, from 1991 until 1998, appears to be characterised mainly by growth divergence between the US, Europe and Japan; effectively a leap forward by the US. Once again, this

\footnotetext{
${ }^{11}$ The impulse to growth under communism would become based on the electricity revolution and the scientific Tayloristic division of labour organisation.

${ }^{12}$ See e.g. the various contributions to the so-called Automation debate (US Senate Committee, 1966).
} 
US growth divergence took place despite a major convergence in aggregate economic indicators such as inflation, long-term interest rates and public spending. It is important to re-situate in its recent historical context the continuing unexpected nature of this emerging growth divergence. First and foremost, few authors predicted the slow-down of Japanese growth. At the same time, many others predicted rapid growth in Europe because of the internal economic integration deepening process (the 1992 Single Market) and the expected rapid catching up of Eastern European countries to EU income and consumption levels. The ultimate paradox of macro-economic convergence is probably best illustrated by the arrival of the Euro on January 1st 1999, accompanied by a significant slow-down of growth across EU member countries, again very much in contrast to expectations and forecasts. However, the collapse of US growth predicted since the mid-1990s as a result of its low savings rate, high trade deficit and unsustainable growth in stock market prices failed to occur.

Hence, growth divergence amongst the Triad countries has been a dominant feature of the 1990s.

Underlying the growth process over the last ten years, some other, new factors appear to have emerged, particularly in the US. More than any other country in the world, the US economy appears to have benefited from faster application and implementation of new technologies, more rapid uptake of the new so-called 'information highways' infrastructure, and more successful world-wide commercial exploitation of these growth opportunities. In short, the US seems to have been the most successful country in making its transition to a knowledge-based economy. This is not the place to go into a discussion about the sustainability of such growth divergence process particularly in view of the open, global financial and information networks. Nevertheless, the process as it appears to have evolved over the last ten years is remarkable and is well worth some further investigation.

In our view, the shift towards a knowledge-based economy is closely related to three separate factors, which will be discussed in the next sections.

\subsection{Investing in knowledge: mobilising private capital}

There is first of all the purely nominal, 'hype' type of increase in general recognition throughout the 
economic system the business community, the financial world, public policy makers about the importance of knowledge and knowledge accumulation for economic growth. Knowledge is of course far from a new concept and many economists, going back to such classical economists as Smith, Ricardo and Marx to Schumpeter, have paid much attention to the process and nature of knowledge accumulation for economic growth. Despite its recent revival, the dominance of neo-classical growth theory over the post-war period appears from this perspective more like a parenthesis in the history of economic thought.

Yet, the increased attention given to knowledge accumulation has made economists across disciplines much more aware that knowledge accumulation can to some extent also be analysed like the accumulation of other capital goods, whereby economic principles can be applied within particular boundaries to the 'production' and 'exchange' of knowledge. Based on the large amount of appreciative theorising emerging from the economics of technological change and innovation (Nelson, 1995, Freeman and Soete, 1997), knowledge has specific features of its own. Nevertheless, it can be 'produced' and used in the production of other goods, even in the production of itself, similar to other capital goods. It also can be stored and will be subject to depreciation, when skills deteriorate or people no longer use particular knowledge and 'forget'. It might even become obsolete, when new knowledge supersedes and renders it worthless.

Part of the measurement debate about the contribution of so-called intangibles to capital formation, whether at the level of the national accounts of a country (Bos, 1997) or at the level of the capitalised stock value of a company (Edvinsson and Malone, 1997, Stewart, 1997) reflects this renewed awareness of the importance of knowledge accumulation for growth and individual firms' competitiveness.

One may argue that in the US in particular the early recognition by the financial world of the intrinsic value of knowledge accumulation has been behind a much greater readiness of the financial sector to invest in new, often purely knowledge-based firms. From this perspective, the growth of an effective venture capital market whereby the resources to invest in knowledge accumulation could be extracted from the financial market appears a crucial institutional innovation. Both in Japan and Europe (with the exception of the UK and to a lesser extent the Netherlands), the financial sector remained heavily 'material'-biased, often being formally involved or part of the large industrial firms' management. 
Hence, the total market capitalisation of firms in the US (and the UK) is much larger than in Japan or continental European countries as compared to their respective GDPs. Furthermore, the largest capitalised firms in the US are increasingly involved in knowledge accumulation activities rather than just material goods.

As Schumpeter in particular emphasised, the stock market was an essential institutional innovation accompanying the fourth Kondratief. It could well be argued that venture capitalists, NASDAQ and other financial innovations have allowed for the mobilisation of private capital for investment in knowledge activities and have thus become an essential institutional innovation for the emerging knowledge-based economy. By the same token, at the macro-economic level, given the importance of the stock market for additional income and earnings supplements (payments in options) for high-skilled knowledge workers, a major macro-economic innovation was introduced in the US under the reign of Alan Greenspan. As a result, US monetary policy started to focus much more on the stock market developments than money supply, hence signalling a dramatic shift in aim and purpose of the role of fiscal and monetary policy in a knowledge-based economy. Thus, while fiscal and budgetary policy is heavily restricted and focussed on the long term (ageing of population, health costs, etc.), monetary policy is increasingly relaxed and unrelated to inflationary fears and pressures but rather enabling investments in new knowledge areas and further stock market valuation and expansion. The difference with Europe is from this latter perspective probably most striking. Despite restrictive budgetary policies linked to the fiscal Maastricht convergence, monetary policy continues to be over-restrictive and dominated by German pre knowledge-based economy inflationary obsession.

\subsection{Information highways infrastructure and 'new' ICT growth}

The growing economic and policy consensus on the importance of knowledge accumulation for economic growth and international competitiveness is without any doubt also closely related to the emergence of the cluster of new information and communication technologies (ICTs). These technologies have resulted in a dramatic decline in the price of information processing; in a technological-driven 'digital convergence' between communication and computer technology; and last but not least in a rapid growth of international electronic networking. 
From this perspective, ICTs are in the real sense of the word an 'information' technology, the essence of which consists of the increased memorisation and storage, speed, manipulation and interpretation of data and information: in short what has been characterised as the 'codification' of information and knowledge. As a consequence it makes codified knowledge, data and information more accessible than before to all sectors and agents in the economy linked to information networks or with the knowledge of how to access such networks. This is of course not to deny the importance of 'tacit' knowledge; on the contrary, as more and more knowledge becomes codifiable, the remaining non-codifiable part becomes even more crucial, as we discuss further below.

Again the US appears to have been much more capable of benefiting from the emerging ICTs. There has been a dramatic revival of the US semiconductor industry following the US-Japanese semiconductor trade agreement effectively providing breeding space for such revival. On the other hand the alliance between the software and semiconductor industry has allowed for effective commercial exploitation of technological improvements in the computer industry. Authors such as John Zysman refer in this context to the notion of 'wintelism': the combination of continuous technological improvements (e.g. Pentium from Intel) in chip performance and operating systems such as windows (from Microsoft) requiring extensive performance capacity. Thanks to the combination of free local telecom access, expertise in hardware and software network technologies going back to DARPA and ATT (e.g. Sun and the software languages UNIX, Java and now Jini), and the development of a universal Internet Protocol (Netscape), Internet use rose rapidly outside of the traditional scientific community and was quickly taken up by businesses and individuals. Finally, the availability of an extensive content (film, television, radio, press) sector provided a rapid take-off in terms of new Internet content services.

The result has been that the US lead the world with maybe only one exception (Finland), in Internet use and pricing, in number of websites, Information Service Providers, hits, sales on e-commerce, etc. The growth in employment in these ICT-related sectors has been significant and is expected to continue to grow as Tables 5 and 6 illustrate, as has been the volume of international trade generated. The international US competitiveness in these sectors has undoubtedly been greatly enhanced by the sometimes forceful imposition worldwide (China) of strong intellectual property regimes (see for instance the systematic implementation methods of the Business Software Alliance in individual 
countries) in the area of copyrights, trademarks and authorship-rights (extended recently from 50 to 70 years). Here too as Table 7 illustrates employment growth has been significant.

\section{Table 5}

Employment in selected e-commerce-related US industries: estimates and projections

\begin{tabular}{|c|c|c|c|c|c|c|c|}
\hline & \multirow[t]{2}{*}{ US SIC Industry } & \multicolumn{2}{|c|}{1997} & \multicolumn{2}{|l|}{2006} & \multicolumn{2}{|c|}{$\begin{array}{l}\text { Employment } \\
\text { Change 97-06 } \\
\end{array}$} \\
\hline & & $\begin{array}{l}\text { Number } \\
\text { (x 1.000) }\end{array}$ & Share & $\begin{array}{l}\text { Number } \\
\text { (x 1.000) }\end{array}$ & Share & Number & $\%$ \\
\hline 357 & Computer and telecom eq. & 379 & 0.30 & 314 & 0.23 & $-65,000$ & -1.72 \\
\hline 481 & Telecommunications & 922 & 0.74 & 925 & 0.66 & 2,762 & 0.03 \\
\hline 272 & Periodicals & 133 & 0.11 & 140 & 0.10 & 7,425 & 0.56 \\
\hline 596 & Non-store retailer & 342 & 0.27 & 350 & 0.25 & 8,108 & 0.24 \\
\hline 621 & Security and commodity brokers & 591 & 0.47 & 740 & 0.53 & 149,029 & 2.52 \\
\hline 720 & Personal services & 1,221 & 0.98 & 1,294 & 0.93 & 73,293 & 0.60 \\
\hline 731 & Advertising & 256 & 0.21 & 270 & 0.19 & 14,268 & 0.56 \\
\hline 733 & Mailing, reproduction etc. & 313 & 0.25 & 361 & 0.26 & 47,676 & 15.2 \\
\hline 737 & Computer and data-processing & 1,342 & 1.08 & 2,509 & 1.80 & $1,167,289$ & 8.70 \\
\hline 738 & Miscellaneous business services & 1,691 & 1.36 & 2,086 & 1.50 & 395,213 & 2.34 \\
\hline 781 & Motion picture production & 256 & 0.21 & 328 & 0.24 & 71,969 & 2.81 \\
\hline 820 & Education, pub. and priv. & 2,081 & 1.67 & 2,478 & 1.78 & 397,006 & 1.91 \\
\hline \multirow[t]{2}{*}{890} & Services, n.e.c. & 49 & 0.04 & 62 & 0.04 & 13,397 & 2.76 \\
\hline & Total economy & 124,471 & & 139,192 & & $14,721,407$ & 1.18 \\
\hline
\end{tabular}

Source: OECD (1998)

But the final consumer end of these new ICT-based sectors is of course only one part of the 'new' growth story. Probably even more important has been the impact on firms' internal efficiency, the impact of so-called business-to-business e-commerce (OECD, 1998). The increased potential for codification and transferability allowed for by ICT allows indeed also for significant reductions in transaction costs; for a process of des-intermediation and decentralisation of activities and more global direct distribution and access (Soete, 1998).

The importance of access brings to the forefront the overriding importance of new communication 
infrastructures, as enabling factor for both cost reduction and the foundation of new markets.

Table 6

Contribution $^{1}$ of selected industries to average annual employment growth rate, US and EU-10

\begin{tabular}{|c|c|c|c|c|}
\hline & \multicolumn{2}{|c|}{$\begin{array}{c}\% \text { of total } \\
\text { employment }\end{array}$} & \multicolumn{2}{|c|}{$\begin{array}{l}\text { Contribution to total } \\
\text { employment growth }\end{array}$} \\
\hline & US 1996 & $\mathrm{EU}^{2} 1996$ & $\begin{array}{c}\text { US 93-96 } \\
(\%)\end{array}$ & $\begin{array}{c}\text { EU } 93-96 \\
(\%)\end{array}$ \\
\hline Hardware and communication equipment & 1.4 & 2.0 & 0.034 & 0.002 \\
\hline Computer and data-processing activities & 1.0 & 0.8 & 0.090 & 0.078 \\
\hline Communications & 1.0 & 1.8 & 0.021 & 0.017 \\
\hline Financial intermediation & 5.7 & 4.3 & 0.038 & -0.013 \\
\hline Trade & 22.6 & 13.4 & 0.570 & 0.094 \\
\hline Total & 31.7 & 22.3 & 0.751 & 0.178 \\
\hline Others & 68.3 & 77.7 & 1.521 & 0.330 \\
\hline Total employment growth rate & & & 2.272 & 0.508 \\
\hline
\end{tabular}

${ }^{1}$ Contributions are calculated as the growth rates weighted by average shares in employment

${ }^{2}$ Belgium, Denmark, France, Greece, Italy, Luxembourg, Netherlands, Portugal, Spain, UK

Source: OECD (1998)

Table 7

Employment in the US copyright industries

\begin{tabular}{lrrrrrrrrr}
\hline \multicolumn{1}{c}{ Sector } & \multicolumn{4}{c}{ Employment (x 1.000) } & \multicolumn{3}{c}{ Share of US workforce (\%) } \\
\hline & 1977 & 1987 & 1996 & 2006 & 1977 & 1987 & 1996 & 2006 \\
\hline Publishing & 697 & 885 & 1,538 & 1,501 & 0.76 & 0.79 & 1.26 & 1.08 \\
Computer & 187 & 631 & 1,208 & 2,509 & 0.20 & 0.56 & 0.99 & 1.80 \\
Radio and TV & 162 & 225 & 243 & 245 & 0.18 & 0.20 & 0.20 & 0.18 \\
Advertising & 132 & 217 & 242 & 270 & 0.14 & 0.19 & 0.20 & 0.19 \\
Motion picture & 214 & 236 & 522 & 628 & 0.23 & 0.21 & 0.43 & 0.45 \\
Theatrical prod. & 66 & 117 &.. &.. & 0.07 & 0.10 &.. &.. \\
Records and tape & 27 & 21 &.. &.. & 0.03 & 0.02 &.. &.. \\
\hline Total & 1,484 & 2,331 & 3,753 & 5,153 & 1.6 & 2.07 & 3.08 & 3.7 \\
\hline
\end{tabular}

Source: OECD (1998) 


\subsection{A new 'commodification' process of knowledge}

Partly also as a result of the new ICTs, the perception of the nature of innovation processes has also changed significantly over the last decade. We agree with David and Foray (1995) that innovation capabilities are increasingly seen less in terms of the ability to discover new technological principles, than in terms of the ability to exploit systematically the effects produced by new combinations and use of pieces in the existing stock of knowledge. This model implies, as David and Foray have argued, to some extent more routine use of a technological base allowing innovation without the need for 'leaps' in technology. It thus requires much more systematic access to the state-of-the-art; universities, public and private research centres will introduce procedures for the dissemination of information regarding the stock of technologies available, so that individual innovators can draw upon the work of other innovators.

In other words, the science and technology system is shifting towards a more complex 'socially distributed' structure of knowledge production activities, involving in particular a great diversity of organisations having an explicit goal of producing knowledge. The old system was based on a simple dichotomy between deliberate learning and knowledge generation (R\&D laboratories and universities) and activities of production and consumption where the motivation for acting was not to acquire new knowledge but rather to produce or use effective outputs. Combined with the intensive use of new ICTs, this has led to a partial collapse of the old dichotomy with a proliferation of new places having the explicit goal of producing knowledge and undertaking deliberate research activities. Knowledge production has if anything also been subject to reorganisation, outsourcing and dis-intermediation following the process of 'codification' of information and knowledge.

Once again, the US science and technology system seems to have been far more successful in responding to this new, more complex knowledge production model. First of all, as Nelson (1993) has described in great detail, the US national innovation system has traditionally been characterised by a university system which was diverse (public-private; local-state; specialised-broad), closely integrated with the private sector, and particularly strongly performing. Second, with the Bayh-Doyle act of 1981, the US has obtained strong first-mover advantages in valorising particular pieces of university research, one might say the 'commodification' of pieces of knowledge. Such commodification process has 
undoubtedly restricted the public use of university research results. Yet it has provided a major incentive to private firms to rely on university research for some of their own, too complex fundamental research activities and created a legally clear environment for university spin-offs providing a major incentive for university staff to set up new private ventures. Europe is lagging behind in allowing universities to take out patents (in most European countries, the individual university professors take out the patent) and shifting patent law to allow for university research to be patented. In fact, this has meant that in areas such as biotechnology and medical technology the leading position of some European countries has been rapidly eroded over the 1980s and 1990s. Third, while awareness of both European and Japanese structural weakness in their innovation system, and in particular their university system, increased over this period, policy action was not forthcoming and remained dominated by old national institutional bottlenecks. Thus, and particularly with respect to European Commission policy initiatives, the focus continued to be primarily on fostering intra-European co-operation in the field of pre-competitive $R \& D$, university researchers, and various support programmes for particular technology fields: the so-called framework programmes and other related technological support programmes. Unfortunately, compared to national resources the EU resources available were too limited to make any impact on shifting or redirecting countries' own national priorities in supporting investment in knowledge accumulation. At the same time, the policies seemed overly dominated by the overriding aim of intra-European research collaboration. While the latter might still be welcome in some cases, the essential research collaboration in the new complex knowledge production model is more likely to be of a global nature, going well beyond the European borders, and unlikely to allow itself to be described in terms of pre-competitive. Hence, there could well have been a case of knowledge acquisition 'diversion', the intra-European knowledge exchange and networking having taken place at the expense of extra-European exchange and networking. It is what one of us has called (Soete, 1996) the 'European paradox': as Europe invested in intra-European research, in the collaboration and exchange of scientific knowledge among European scientists, or even in the technological strenghtening of the competitive potential of European firms, the advantages of such geographically 'bounded' collaboration became marginal, given the dramatically increased opportunities for the fast international exchange of information and cooperation. 


\section{Conclusions}

We have in this empirical paper briefly reviewed the growth experience of the industrialised OECD countries over the post-war period. This growth experience seems to fit some of the various later phases of the Fourth Kondratief wave: rapid growth convergence towards US production and income levels in the 1950-73 period, strongly influenced by the massive war destruction in continental Europe and Japan; a transition period with significant institutional and policy mismatches emerging over the 197391 period but still characterised by strong growth convergence; and finally a recent period of growth divergence between the US, Europe and Japan. While analysed at the aggregate level, the model developed in the paper nevertheless illustrated how the most recent period appears to be related to shifts in the particular contributions of various forms of knowledge accumulation. As we argued in the last section of the paper, the latter seems to be characterised by a number of features which the US has been much more successful in exploiting to its own advantage. Whether this particular success remains, of course, to be seen.

The particular European and Japanese mismatches both in macro-economic policy and institutional flexibility and adaptability are unlikely to last for ever. At the same time, the US growth path appears from more than one perspective unsustainable, but that of course is another story, which has not been addressed here. 


\section{References}

Abramovitz, M. A. (1979), Rapid Growth Potential and its Realisation : The Experience of Capitalist Economies in the Postwar Period, in: Malinvaud, E. (ed.), Economic Growth and Resources, vol. 1 The Major Issues, proceedings of the fifth World Congress of the IEA, London: Macmillan, pp. 1-51.

Abramovitz, M. A. (1986), Catching Up, Forging Ahead and Falling Behind, Journal of Economic History, vol. 46, pp. 385-406.

Abramovitz, M. A. (1992), Catch Up and Convergence in the Postwar Growth Boom and After, Paper presented at the workshop on Historical Perspectives on the International Convergence of Productivity, New York, April 23-24, 1992.

Baumol, W. J. (1986), Productivity Growth, Convergence, and Welfare: What the Long-Run Data Show, American Economic Review, vol. 76, no. 5, pp. 1072-1085.

Baumol, W. J., S. A. Batey Blackman and E. N. Wolff, (1989), Productivity and American Leadership: The Long View, Cambridge MA.: MIT Press.

Bénabou, R. (1996), Inequality and Growth, in: Bernanke, B. S. and J. Rotemberg (eds.), NBER Macroeconomics Annual, vol. 11, Cambridge MA.: MIT Press, pp. 11-74.

Ben-David, D. and M. B. Loewy (1998), Free Trade, Growth and Convergence, Journal of Economic Growth, vol. 3, no. 2, pp. 143-170.

Bos, F. (1997), Human Capital and Economic Growth: a National accounting Approach, Paper presented for the Applied Econometric Association Conference, Maastricht, 16 May 1997.

Cornwall, J., (1977), Modern Capitalism. Its Growth and Transformation, London: Martin Robertson.

Dowrick, S. and D. T. Nguyen, (1989), OECD Comparative Economic Growth 1950-85: Catch-Up and Convergence, American Economic Review, vol. 79, pp. 1010-1030.

Edvinsson. L. and M. Malone (1997), Intellectual Capital: the proven way to establish your company's real value by measuring its hidden brainpower, London: Judy Piatkus.

Fagerberg, J. (1988), Why Growth Rates Differ, in: Dosi, G., Freeman, C., Nelson, R., Silverberg, G. and L. Soete (eds.), Technical Change and Economic Theory, London: Pinter, pp. 432-457.

Freeman, C. and L. Soete (1997), The Economics of Industrial Innovation, 3rd edition, London: Pinter. Gerschenkron, A., (1962), Economic Backwardness in Historical Perspective, Cambridge Mass.: Harvard UP.

Goldin, C. and L. F. Katz (1998), The Origins of Technology-Skill Complementarity, Quarterly Journal of Economics, vol. 113, no. 3, pp. 693-732.

Hollanders, H., L. Soete and B. ter Weel (1999), World Knowledge Report, Edward Elgar: London, forthcoming.

Lucas, R. (1993), Making a Miracle, Econometrica, vol. 61, pp. 251-272.

MacLeod, R. (1986), Technology and the Human Prospect, London: Pinter. 
Mankiw, N. G., Romer, D. and D. Weil, (1992), A Contribution to the Empirics of Economic Growth, Quarterly Journal of Economics, 152, pp. 407-437.

Nelson, R. (1993), National Innovation Systems, New York: Oxford University Press.

Nelson, R. (1995), Recent Evolutionary Theorizing about Economic Change, Journal of Economic Literature, XXXIII, March, pp.48-90.

OECD (1998), A Borderless World: realising the Potential of Global Electronic Commerce, DSTI/ICCP(98)15, Paris, mimeo.

Pavitt, K. and L. Soete (1982), International Differences in Economic Growth and the International Location of Innovation, in: Giersch, H. (ed.), Emerging Technologies: The Consequences for Economic Growth, Structural Change and Employment, Mohr: Tübingen.

Soete, L. (1986), Technological Innovation and long waves, in R. MacLeod (ed.), Technology and the Human Prospect, London: Pinter, pp. 214-238.

Soete, L. (1997), The impact of globalization on European economic integration, IPTS Report, nr.15, June, pp. 21-28.

Soete, L. (1998), Electronic Commerce and the Information Higways, paper prepared for the CIRANO/Industry Canada Coneference, Mont Tremblant, September, mimeo.

Soete, L. and B. Verspagen (1994), Competing for Growth: The Dynamics of Technology Gaps, in: Pasinetti, L. L. and R. M. Solow (eds.), Economic Growth and the Structure of Long-Term Development, MacMillan: London, pp. 272-299.

Stewart, T. (1997), Intellectual Capital: The New Wealth of Organisations, New York: Currency/Doubleday.

US Senate Committee (1996), Automation Debate, Washington.

Verspagen, B. (1991), A New Empirical Approach to Catching Up or Falling Behind, Structural Change and Economic Dynamics, vol. 2, pp. 359-380.

Verspagen, B. (1993), Uneven Growth between Interdependent Economies. An Evolutionary View on Technology Gaps, Trade and Growth, Edward Elgar: London.

Verspagen, B. (1994), Technology and Growth: the Complex Dynamics of Convergence and Divergence, in: Silverberg, G. and L. Soete (eds.), The Economics of Growth and Technical Change: Technologies, Nations, Agents, Edwar Elgar, Aldershot, pp. 154-181. 


\section{Annex 1. List of Countries}

\section{Sub-Saharan Africa}

Angola, Benin, Botswana, Burkina Faso, Burundi, Cameroon, Cape Verde, Central African Republic, Chad, Comoros, Congo Dem. Rep., Congo Rep., Cote d'Ivoire, Djibouti, Ethiopia, Gabon, Gambia, Ghana, Guinea, Guinea-Bissau, Kenya, Lesotho, Liberia, Madagascar, Malawi, Mali, Mauritania, Mauritius, Mozambique, Namibia, Niger, Nigeria, Reunion, Rwanda, Senegal, Seychelles, Sierra Leone, Somalia, South Africa, Sudan, Swaziland, Tanzania, Togo, Uganda, Zambia, Zimbabwe

\section{Middle East and North Africa}

Algeria, Bahrain, Cyprus, Egypt, Iran, Iraq, Israel, Jordan, Kuwait, Malta, Morocco, Oman, Qatar, Saudi Arabia, Syrian Arab Republic, Tunisia, United Arab Emirates, Yemen

\section{South East Asia}

Bangladesh, Hong Kong, China, Korea Rep., Lao PDR, Malaysia, Singapore, Taiwan

\section{Other Asia and Pacific}

Bhutan, China, Fiji, India, Indonesia, Mongolia, Myanmar, Nepal, Pakistan, Papua New Guinea, Philippines, Samoa, Solomon Islands, Sri Lanka, Thailand, Tonga, Vanuatu

\section{Middle and South America}

Argentina, Bahamas, Barbados, Belarus, Bolivia, Brazil, Chile, Colombia, Costa Rica, Dominica, Dominican Republic, Ecuador, El Salvador, Grenada, Guatemala, Guyana, Haiti, Honduras, Jamaica, Mexico, Nicaragua, Panama, Paraguay, Peru, Puerto Rico, St. Kitts and Nevis, St. Lucia, St. Vincent and the Grenadines, Suriname, Trinidad and Tobago, Uruguay, Venezuela

\section{OECD}

Australia, Austria, Belgium, Canada, Denmark, Finland, France, Germany, Greece, Iceland, Ireland, Italy, Japan, Luxembourg, Netherlands, New Zealand, Norway, Portugal, Spain, Sweden, Switzerland, Turkey, United Kingdom, United States

\section{Eastern Europe}

Bulgaria, Czech Republic, Former East Germany, Former Soviet Union, Hungary, Poland, Romania, Yugoslavia FR 